\title{
Clopidogrel Within Few Hours of Coronary Artery Bypass Grafting Does Significantly Increase the Risk of Bleeding
}

\author{
Emad M. Hijazi ${ }^{\mathrm{a}, \mathrm{b}}$, Ghassan S Musleh ${ }^{\mathrm{a}}$
}

\begin{abstract}
Background: Postoperative bleeding after coronary artery surgery is partly related to platelet dysfunction. The aim of this study was to evaluate the effects of a single loading dose of clopidogrel (300 $\mathrm{mg}$ ) before coronary angiography on bleeding and use of blood and blood products after emergency coronary artery bypass surgery (CABG).
\end{abstract}

Methods: This is a nonrandomized observational prospective study between January, 2006 till December 2009, at a university hospital, we compare the results of a cohort of 65 patients who received 300 mg clopidogrel during coronary angiography that was followed by emergency CABG (group A or study group) to a cohort of 206 patients who underwent elective coronary artery bypass surgery during the same period by the same surgeons in whom clopidogrel was stopped 7 days before surgery (Group B or control group). Emergency surgery was done because of critical coronary anatomy or because of ongoing chest pain. All patients in the two groups were kept on $100 \mathrm{mg}$ of aspirin until the day of surgery. Outcome data used to compare the two groups, Chest tube drainage in first 12 hours $(12 \mathrm{~h})$, need for re-exploration and use of blood and blood product transfusion were prospectively collected.

Results: Postoperative bleeding, reoperation rates for bleeding and use of blood products are significantly more in those who received a loading dose of clopedogril within few hours of CABG (group A) compared to those who stopped clopedogril for a week before CABG.

Conclusions: Preoperative $300 \mathrm{mg}$ of clopidogrel is associated with significant increase in post operative bleeding, need for sur-

\footnotetext{
Manuscript accepted for publication September 27, 2012

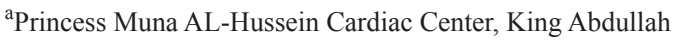
University Hospital, Faculty of Medicine, Jordan University of Science and Technology, Jordan

${ }^{\mathrm{b}}$ Corresponding author: Emad M. Hijazi, Princess Muna AL-Hussein Cardiac Center, King Abdullah University Hospital, Faculty of Medicine, Jordan University of Science and Technology, Jordan. Email: emad_hijazi@hotmail.com
}

doi: http://dx.doi.org/10.4021/cr226e gical exploration and use of blood and blood product transfusion after CABG.

Keywords: Coronary artery bypass; Bleeding; Clopidogrel

\section{Introduction}

For secondary prevention of coronary and cerebrovascular ischemic events, many patients are now receiving long-term clopidogrel (Plavix) with or without aspirin [1-3].

Clopidogrel is a potent inhibitor of platelet aggregation that works by irreversible blockage of adenosine diphosphate (ADP) mediated platelet activation. It has been demonstrated to reduce early stent failure [4], improve outcomes in acute coronary syndromes [5], and decrease all cause cardiovascular mortality [6].

For those who need emergency coronary artery bypass surgery (CABG), it may not always be possible to stop the antiplatelets before surgery. In those cases, there is an increased risk of postoperative bleeding [7].

Reoperation rate after $\mathrm{CABG}$ for bleeding is approximately $2 \%$ to $3 \%$. Half of those reoperations have no identifiable surgical cause of bleeding $[8,9]$ and most likely caused by coagulopathy. An increase rate in postoperative bleeding results in a higher incidence of re-exploration and blood transfusion related complications [10] as well as prolonging the patients' length of stay [8].

Advanced age and cardiopulmonary bypass time (CPB) are factors that enhance the postoperative bleeding after CABG $[8,9]$.

Controversy remains about the anti-aggregation agents that affecting thrombocyte function whether it does really increase the tendency of patients to have postoperative bleeding complications [11-13].

\section{Methods}

This is a prospective study between January, 2006 till December 2009, involved two groups of patients. Group A (65 
Table 1. Preoperative and Intraoperrative Variable

\begin{tabular}{|c|c|c|c|}
\hline & $\begin{array}{l}\text { Clopidogrel group } \\
\text { (65 cases) }\end{array}$ & $\begin{array}{l}\text { No Clopedogril group } \\
\text { (206 cases) }\end{array}$ & P value \\
\hline The average age & $\begin{array}{l}64.9 \text { years (range, } \\
39 \text { to } 83 \text { years) }\end{array}$ & $\begin{array}{l}63.2 \text { years (range, } \\
36 \text { to } 80 \text { years) }\end{array}$ & \\
\hline Male & 40 & 146 & 0.157 \\
\hline Female & 25 & 60 & \\
\hline Age & 57.3 & 61 & 0.440 \\
\hline Diabetes & 26 & 100 & 0.228 \\
\hline C.R.F & 1 & 2 & 0.562 \\
\hline P.V.D & 5 & 15 & 0.548 \\
\hline COPD & 12 & 29 & 0.389 \\
\hline Smoking & 42 & 152 & 0.152 \\
\hline Heamoglubin & 11.9 & 12.3 & 0.155 \\
\hline X Clamp time (minutes) & 39 & 36 & 0.126 \\
\hline Bypass time (minutes) & 76 & 83 & 0.190 \\
\hline No of grafts & 2.7 & 3.1 & 0.359 \\
\hline Steroid use & 3 & 5 & 0.294 \\
\hline Obesity $\left(\mathrm{BMI}>25 \mathrm{~kg} / \mathrm{m}^{2}\right)$ & 8 & 11 & 0.056 \\
\hline
\end{tabular}

TIA: Transient ischemic attacks; C.R.F: Chronic renal failure; P.V.D: Peripheral vascular disease; COPD: Chronic obstructive pulmonary disease; BMI: Body mass index.

patients) who received $300 \mathrm{mg}$ of clopedogril at the time of coronary angiogram followed by emergency coronary artery bypass surgery (CABG) for critical coronary anatomy or ongoing chest pain. They were transferred to operating theatre within 2 hours of their angiography. And group B ( $206 \mathrm{~Pa}-$ tients) who stopped clopedogril for a 7 days before elective coronary artery bypass surgery all patients in both groups were kept on $100 \mathrm{mg}$ of aspirin till the day of surgery. All first time isolated CABGs that were done during the study period were included in the study. Those who were older than 70 years, Redo CABG, CABG plus other interventions and those who were on warfarin were excluded from the study. None of our cases in either group received low molecular weight heparin in the preoperative period. Clopidogrel was the only anti-platelet agent to be given to the patients in the emergency group. None of them received GPIIb/IIIA inhipitors, heparin or low molecular weight heparin while waiting for operation. The median time between receiving $300 \mathrm{mg}$ of clopedogril and operation was 2.15 hours (range 1.30 -
2.45 hours). All cases were done on pump, none received anti-fibrinolytic agents. Pre-operative patient characteristics and postoperative data were prospectively collected. Preoperative demographic characteristics and risk factors in both groups were prospectively collected (Table 1).

To evaluate post operative bleeding, data about chest tube drainage during the first 12 hours the need for re-exploration and use of blood and blood product transfusion were collected (Table 2).

The trigger to give blood is Haemoglubin level less than $10 \mathrm{~g} / \mathrm{dL}$. The trigger to give platelets is platelet count less than 150 , we did not use sophisticated platelet function tests. The trigger to give Fresh Frozen Plasma is PT $>18$. There was no clinical or laboratory evidence of preoperative bleeding disorders any patient in both groups. The study has been and approved by the ethical committee at Jordan University of Science and Technology in Jordan. The data were analyzed using the Statistical Package for Social Sciences (SPSS, version 19). Frequencies, percentages, mean, and median were 
Table 2. Results

\begin{tabular}{|c|c|c|c|}
\hline & \multicolumn{2}{|c|}{ Group } & \multirow{2}{*}{ Total } \\
\hline & Clopedogril Group & $\begin{array}{l}\text { No Clopedogril } \\
\text { Group }\end{array}$ & \\
\hline Blood Transfusion & & & $<0.001$ \\
\hline $1-2$ & $0(0.0)$ & $186(90.3)$ & \\
\hline 3 & $20(30.8)$ & $20(9.7)$ & \\
\hline $4-5$ & $45(69.2)$ & $0(0.0)$ & \\
\hline FFP Transfusion & & & $<0.001$ \\
\hline $4-6$ & $16(24.6)$ & $206(100.0)$ & \\
\hline $8-10$ & $49(75.4)$ & $0(0.0)$ & \\
\hline Cryo Transfusion & & & $<0.001$ \\
\hline 0 & $0(0.0)$ & $206(100.0)$ & \\
\hline $6-8$ & $65(100.0)$ & $0(0.0)$ & \\
\hline Platelets Transfusion & & & $<0.001$ \\
\hline 4.00 & $0(0.0)$ & $170(82.5)$ & \\
\hline 6.00 & $25(38.5)$ & $36(17.5)$ & \\
\hline 10.00 & $40(61.5)$ & $0(0.0)$ & \\
\hline Mediastinal drainage, mean (SD), median (mL) & $1230.6(118.5) ; 1210.0$ & $791.3(117.4) ; 785.0$ & $<0.001$ \\
\hline ITU stay (days) & 3.3 & 3.1 & 0.151 \\
\hline Total Hospital stay (days) & 7.1 & 7.14 & 0.187 \\
\hline Re-exploration-Number of patients & $9(13.8 \%)$ & $6(2.9 \%)$ & 0.001 \\
\hline
\end{tabular}

${ }^{*}$ Cryo. Transfusion, Blood Transfusion, FFP Transfusion, Platelets Transfusion, Platelets Transfusion $=($ Units $)$

used to describe the data wherever appropriate. Chi-square test was used to test the significance of the differences in the distribution of the studied variables between the two groups of patients and Mann-Whitney test to test for the significance of the differences between medians. A P-value of $<0.05$ was considered statistically significant.

\section{Results}

Postoperative data are presented in (Table 2). There was no significant difference between the haemoglubin levels between the two groups $(11.9 \mathrm{~g} / \mathrm{dL}$ for the clopedogril group versus $12.3 \mathrm{~g} / \mathrm{dL}$ for control group), Operative data showed no statistically significant difference between the two groups regarding Bypass time and aortic cross clamp time. Regard- ing the number of grafts there was 2.7 grafts per case for Clopedogril group versus 3.1 grafts for the control group. The use of internal mammary artery was significantly less in the emergency group $(53 \%(34 / 65)$ of Clopedogril group versus $86 \%(177 / 206)$ of the control group), and this is due to many causes as, patients hemodynamic instability during anesthesia (ECG changes, critical drop of blood pressure that require early inotrop support and to go on-pump as soon as possible), iatrogenic injury of internal mammary artery during harvesting technique, and critical left anterior descending artery (LAD) lesions with small caliber. All cases in the clopidogrel group received three or more units of packed red blood cells compared to 9.7 of the control group who needed three or more units of blood. This was statistically significant $(\mathrm{P}=0.001)$. Regarding platelets' use $100 \%$ of clopedogril cases received six or more units of platelets' compared 
$17.5 \%$ in the control group ( $\mathrm{P}=0.001), 75 \%$ of clopedogril group received 8 or more units of fresh frozen plasma compared to $0 \%$ in the control group $(\mathrm{P}=0.001)$.

Chest drainage in the first twelve hours in the clopidogrel group averaged at $1,230 \pm 118.5 \mathrm{~mL}$, compared to 791 $\pm 117.4 \mathrm{~mL}$ in the control group. This was also statistically significance $(\mathrm{P}=0.001)$.

Eight patients (13.8\%) of study group required reoperation for persistent postoperative bleeding in the study group compared to 6 patients $(2.9 \%)$ in the control group $(\mathrm{P}=$ 0.001).

Two patients in group clopedogril group and four patients in control group had discrete surgical bleeding sites found at the time of reoperation (2 patients bleeding from a side branch of saphenous vein and 2 patients bleeding from a side branch of LIMA and 2 from veins in the chest wall, LIMA bed). Three patients in group A continued to bleed profusely after re-exploration and were given factor VII.

\section{Discussion}

Antiplatelet therapy is critical in the management of coronary artery disease. For patients undergoing coronary artery bypass graft surgery (CABG), controversy remains regarding the safety of preoperative antiplatelet therapy and the optimal postoperative antiplatelet regimen to maintain graft patency and reduce ischemic events [14]. Englberger reported an increase in bleeding complications with a subsequent need for platelet and fresh frozen plasma transfusions in patients receiving clopidogrel within 3 days of surgery [15]. Yusuf et al [5] recommended that clopidogrel to be stopped 5 days before an elective CABG. Weber et al in their studies on the antiplatelet effect of clopidogrel in healthy volunteers have shown that platelet function requires seven days to recover after complete stoppage of the medication [16].

The American College of Cardiology and American Heart Association guidelines published in 2004 for CABG surgery states that "If clinical circumstances permit, clopidogrel should be withheld for five days before performance of CABG surgery [17].

Chu et al [18] in their prospective study that included 312 consecutive urgent or emergent CABG found that clopidogrel within 4 days of CABG is associated with increased blood losses and reoperation for bleeding. Furthermore, a recent study showed that as many as $5 \%$ of patients presenting for $\mathrm{CABG}$ may require their surgery to be done on urgent or emergency basis after exposure to clopidogrel [19]. For a patient whose CABG cannot be delayed safely, prophylactic platelet transfusion has been suggested [10]. Studies have shown that postoperative blood transfusion is an independent predictor of increased long-term mortality after cardiac surgery and, thus, have a direct impact on patient prognosis [20]. For these unwanted clopidogrel complications after coronary artery bypass surgery a reversible and direct-acting oral P2Y12-receptor antagonist (Ticagrelor),provide more consistent platelet inhibition than does clopidogrel, with more rapid onset and offset of action [21-23]. In the PLATelet inhibition and patient Outcomes (PLATO) trial, long-term reversible P2Y12 inhibition with ticagrelor was better than that with clopidogrel for the prevention of cardiovascular and total death, stent thrombosis, and myocardial infarction without an increase in the rates of major bleeding in a broad population of patients with acute coronary syndromes who were started on treatment as soon as possible after hospital admission [24]. Patients given ticagrelor had significant and clinically relevant reductions in cardiovascular and total deaths, myocardial infarction, and stent thrombosis, without an increase in risk of major bleeding [25].

\section{Limitation of the study}

Although the data were prospectively collected, the study is not a randomized trial and therefore subjected to the selection bias. The other limitation is the fact that all the study group cases were done on emergency basis which will undoubtedly lead to an increase in the incidence of almost all untoward events. Unfortunately we could not recruit elective cases into the study group because of the clear recommendations of stopping clopedogril for at least five days in elective cases.

\section{Conclusion}

The preoperative administration of $300 \mathrm{mg}$ clopidogrel within few hours of coronary artery bypass graft surgery is associated with significant increase of post operative bleeding, surgical re-exploration and use of blood products.

\section{References}

1. Steinhubl SR, Berger PB, Mann JT, 3rd, Fry ET, DeLago A, Wilmer C, Topol EJ. Early and sustained dual oral antiplatelet therapy following percutaneous coronary intervention: a randomized controlled trial. JAMA. 2002;288(19):2411-2420.

2. Alberts MJ, Easton JD. Clopidogrel plus aspirin for stroke prevention. Stroke. 2002;33(11):2546-2547; author reply 2546-2547.

3. Gerschutz GP, Bhatt DL. The Clopidogrel in Unstable Angina to Prevent Recurrent Events (CURE) study: to what extent should the results be generalizable? Am Heart J. 2003;145(4):595-601.

4. Mishkel GJ, Aguirre FV, Ligon RW, Rocha-Singh KJ, Lucore CL. Clopidogrel as adjunctive antiplatelet therapy during coronary stenting. J Am Coll Cardiol. 1999;34(7):1884-1890. 
5. Yusuf S, Zhao F, Mehta SR, Chrolavicius S, Tognoni G, Fox KK. Effects of clopidogrel in addition to aspirin in patients with acute coronary syndromes without STsegment elevation. N Engl J Med. 2001;345(7):494-502.

6. A randomised, blinded, trial of clopidogrel versus aspirin in patients at risk of ischaemic events (CAPRIE). CAPRIE Steering Committee. Lancet. 1996;348(9038):1329-1339.

7. Kang W, Theman TE, Reed JF, 3rd, Stoltzfus J, Weger N. The effect of preoperative clopidogrel on bleeding after coronary artery bypass surgery. J Surg Educ. 2007;64(2):88-92.

8. Dacey LJ, Munoz JJ, Baribeau YR, Johnson ER, Lahey SJ, Leavitt BJ, Quinn RD, et al. Reexploration for hemorrhage following coronary artery bypass grafting: incidence and risk factors. Northern New England Cardiovascular Disease Study Group. Arch Surg. 1998;133(4):442-447.

9. Woodman RC, Harker LA. Bleeding complications associated with cardiopulmonary bypass. Blood. 1990;76(9):1680-1697.

10. Yende S, Wunderink RG. Effect of clopidogrel on bleeding after coronary artery bypass surgery. Crit Care Med. 2001;29(12):2271-2275.

11. Harker LA. Bleeding after cardiopulmonary bypass. $\mathrm{N}$ Engl J Med. 1986;314(22):1446-1448.

12. Tuman KJ, McCarthy RJ, O'Connor CJ, McCarthy WE, Ivankovich $\mathrm{AD}$. Aspirin does not increase allogeneic blood transfusion in reoperative coronary artery surgery. Anesth Analg. 1996;83(6):1178-1184.

13. Sethi GK, Copeland JG, Goldman S, Moritz T, Zadina $\mathrm{K}$, Henderson WG. Implications of preoperative administration of aspirin in patients undergoing coronary artery bypass grafting. Department of Veterans Affairs Cooperative Study on Antiplatelet Therapy. J Am Coll Cardiol. 1990;15(1):15-20.

14. Kulik A, Chan V, Ruel M. Antiplatelet therapy and coronary artery bypass graft surgery: perioperative safety and efficacy. Expert Opin Drug Saf. 2009;8(2):169-182.

15. Englberger L, Faeh B, Berdat PA, Eberli F, Meier B, Carrel T. Impact of clopidogrel in coronary artery bypass grafting. Eur J Cardiothorac Surg. 2004;26(1):96101.

16. Weber AA, Braun M, Hohlfeld T, Schwippert B, Tschope $\mathrm{D}$, Schror K. Recovery of platelet function after discontinuation of clopidogrel treatment in healthy volunteers. Br J Clin Pharmacol. 2001;52(3):333-336.
17. Eagle KA, Guyton RA, Davidoff R, Edwards FH, Ewy GA, Gardner TJ, Hart JC, et al. ACC/AHA 2004 guideline update for coronary artery bypass graft surgery: a report of the American College of Cardiology/American Heart Association Task Force on Practice Guidelines (Committee to Update the 1999 Guidelines for Coronary Artery Bypass Graft Surgery). Circulation. 2004;110(14):e340-437.

18. Chu MW, Wilson SR, Novick RJ, Stitt LW, Quantz MA. Does clopidogrel increase blood loss following coronary artery bypass surgery? Ann Thorac Surg. 2004;78(5):1536-1541.

19. Genoni M, Tavakoli R, Hofer C, Bertel O and Turina M, Clopidogrel before urgent coronary artery bypass graft, J Thorac Cariovasc Surg 12. 2003; 288-289.

20. Engoren MC, Habib RH, Zacharias A, Schwann TA, Riordan CJ, Durham SJ. Effect of blood transfusion on long-term survival after cardiac operation. Ann Thorac Surg. 2002;74(4):1180-1186.

21. Storey RF, Husted S, Harrington RA, Heptinstall S, Wilcox RG, Peters G, Wickens M, et al. Inhibition of platelet aggregation by AZD6140, a reversible oral P2Y12 receptor antagonist, compared with clopidogrel in patients with acute coronary syndromes. J Am Coll Cardiol. 2007;50(19):1852-1856.

22. Husted S, Emanuelsson H, Heptinstall S, Sandset PM, Wickens M, Peters G. Pharmacodynamics, pharmacokinetics, and safety of the oral reversible P2Y12 antagonist AZD6140 with aspirin in patients with atherosclerosis: a double-blind comparison to clopidogrel with aspirin. Eur Heart J. 2006;27(9):1038-1047.

23. Gurbel PA, Bliden KP, Butler K, Tantry US, Gesheff $\mathrm{T}$, Wei C, Teng R, et al. Randomized double-blind assessment of the ONSET and OFFSET of the antiplatelet effects of ticagrelor versus clopidogrel in patients with stable coronary artery disease: the ONSET/OFFSET study. Circulation. 2009;120(25):2577-2585.

24. Wallentin L, Becker RC, Budaj A, Cannon CP, Emanuelsson $\mathrm{H}$, Held $\mathrm{C}$, Horrow J, et al. Ticagrelor versus clopidogrel in patients with acute coronary syndromes. N Engl J Med. 2009;361(11):1045-1057.

25. Cannon CP, Harrington RA, James S, Ardissino D, Becker RC, Emanuelsson H, Husted S, et al. Comparison of ticagrelor with clopidogrel in patients with a planned invasive strategy for acute coronary syndromes (PLATO): a randomised double-blind study. Lancet. 2010;375(9711):283-293. 